\title{
HIGH DEVELOPMENTAL AGE AND POOR HAIR MULTI-ELEMENT PROFILE IN A 3.75-YEAR-OLD GIRL - DIFFERENTIAL RATES IN SHAPING OF BODY ORGAN GROWTH
}

\author{
B. Momčilović ${ }^{1 *}$, A.A. Skalny ${ }^{2}$, J. Prejac $^{3}$, V. Višnjević ${ }^{1}$ \\ ${ }^{1}$ Institute for Research and Development of the Sustainable Eco Systems, Srebrnjak 59, 10000 Zagreb, Croatia \\ ${ }^{2}$ ANO Center for Biotic Medicine, Zemlyanoi val 46, Moscow, 105064, Russia \\ ${ }^{3}$ University Hospital Centre Zagreb, Kišpatićeva 12, 10000 Zagreb, Croatia
}

ABSTRACT. To our knowledge the case of El-Ma is the first to demonstrate that different organs (hair for bio-elements and height \& weight for stature) may have different growth rates at a different period of time, i.e., that partitioning in the intermediary metabolism of the body is changing at the various stages of growth.

KEYWORDS: developmental age, hair element profile, metabolic partitioning.

Recently, we were approached by a mother of three daughters who was worried that her youngest 3 years and 9 month ( $3.75 \mathrm{y})$ old daughter $\mathrm{El} \cdot \mathrm{Ma}$, may have some form of autism. She was concerned that El·Ma's behavior, growth and development were impaired possibly by the mercury poisoning. Indeed, mercury toxicity and poisoning of general population is one of a very prominent environmental health issue on the Internet today (Momčilović et al., 2012). El·Ma psychological examination revealed mild speech problems that have responded to the logopedic exercises and mild difficulties in hand control of her pencil; her EEG was normal. Otherwise, she was a highly developed girl for her age (Table) (Geigy, 1956). Her hair was analyzed at the Center for Biotic Medicine, Moscow, RUSSIA, as already described in a great detail (Momčilović et al., 2007). As a matter of fact, El·Ma's body height $(108 \mathrm{~cm})$ and weight $(21 \mathrm{~kg})$ were comparable to that of an average $\left(\mathrm{P}_{50}\right.$ percentile) close to five years old and six years old girl, respectively. However, her multi-element profile, showed an "across the board" low level of respective bio-element concentrations according to the CBM reference values (Figure) (Momčilović et al., 2007).

Only phosphorus and potassium were in the positive middle what reflects their key role in the hair fiber, a composite multi-layer protein composite formation (Višnjević et al., 2013). We have seen El-Ma's hair multi-element profile before having any other information about her and her health status, and we intuitively expected some growth in stature problems but, counter-intuitively, she was a highly developed girl for her age.

Apparently, the nutrient partition within the intermediary metabolism of the body affects the overall growth and bio-element deposition in the hair such, that the bio-elements were preferentially diverted to the organ growth.

Table. El·Ma weight and height relative to the Geigy reference values for 3.5 and 4 year old girl

\begin{tabular}{|c|c|c|c|c|}
\hline Age (yr) & Percentile (P) & Weight(kg) & Percentile (P) & Height (cm) \\
\hline 3.5 & $>\mathrm{P}_{97}$ & $>20.55$ & $\mathrm{P}_{90}-\mathrm{P}_{97}$ & $105.4-108.0$ \\
\hline 3.75 & $\mathrm{El} \cdot \mathrm{Ma}$ & 21 & $\mathrm{E} \cdot \mathrm{Ma}$ & 108 \\
\hline 4.0 & $\mathrm{P}_{90}-\mathrm{P}_{97}$ & $19.73-1.86$ & $\mathrm{P}_{75}-\mathrm{P}_{90}$ & $105.8-109.6$ \\
\hline
\end{tabular}

\footnotetext{
* Corresponding author 


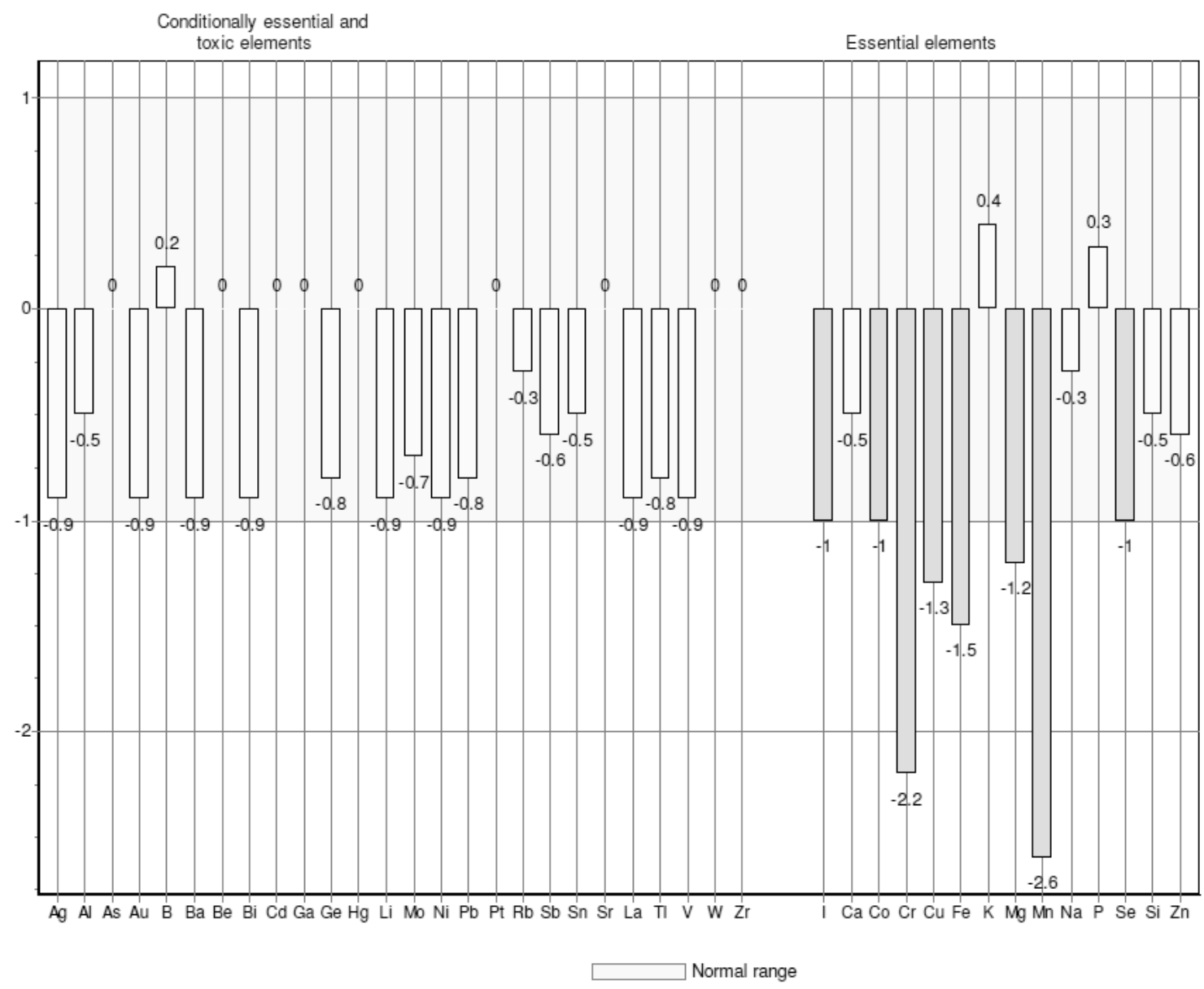

Figure. El-Ma's hair multi-element profile

The results of this clinical case clearly indicate that body growth is not a singular event that would involve all of the organs in the body to the same degree, but that the growth occurs at differential rates for various organs and/or organ systems of the body. Indeed, body growth is a complex, multidimensional phenomenon that is still evading a rigorous definition - current definitions run from an oversimplified "growth is increase in size" to the highly elaborate "growth is the co-ordinated expression of incremental and developmental factors and functions" (Scothorne AJ, 1985). Our knowledge on body growth is mostly related to the growth in stature, i.e., the growth of bones (Tanner, 1981).

\section{REFERENCES}

J.R. Geigy S.A. Normal body measurements during growth // In: Documenta Geigy Scientific Tables, $5^{\text {th }}$ ed. Basle, Switzerland, 1956, pp. 257-266.
Momčilović B., Morović J., Ivičić N., Skalny A.V. Hair and blood multi-element profile for metabolic imaging of the major unipolar depression. Rationale and design // Trace Elements in Medicine 2007, 7(4):35-42.

Momčilović B., Prejac J., Morović S., Novak-Roje M., Višnjević V. Increased hair mercury in an autistic boy of a professional dentist mother // Trace Elements in Medicine 2012, 13(2):34-35.

Scothorne A.J. Early development // In: Forrester JM, ed. in-chief. A companion to medical studies: anatomy, biochemistry, and physiology, $3^{\text {rd }}$ ed., Blackwell Scientific Publications, Oxford, UK, 1985, pp. 15.37-15.45.

Tanner J.M. ed. Control of growth // British Medical Bulletin 1981, 37:207-302.

Višnjević V, Prejac J, Skalny AA, Momčilović B. Human hair phosphorus median concentrations in Croatia, Macedonia, Japan, and the USA does not differ // ISTERH 10, Poster 33, Tokyo, Japan, November 18-22, 2013 


\title{
УСКОРЕННОЕ ФИЗИЧЕСКОЕ РАЗВИТИЕ НА ФОНЕ ПОНИЖЕННОГО СОДЕРЖАНИЯ МАКРО- И МИКРОЭЛЕМЕНТОВ В ВОЛОСАХ ДЕВОЧКИ ТРЕХ ЛЕТ - ОТЛИЧИТЕЛЬНАЯ ЧЕРТА НЕСООТВЕТСТВИЯ РОСТА И РАЗВИТИЯ ОРГАНОВ ТЕЛА
}

\author{
Б. Момчилович ${ }^{1}$, А.А. Скальный ${ }^{2}$, Ю. Преяч ${ }^{3}$, В. $^{1}$ Вишневич \\ ${ }^{1}$ Институт изучения и развития устойчивых экосистем, Загреб, Хорватия \\ ${ }^{2}$ АНО «Центр биотической медицины», Москва, Россия \\ ${ }^{3}$ Университетский клинический центр, Загреб, Хорватия
}

РЕЗЮМЕ. В сообщении описан случай обращения в медицинский центр с подозрением на аутизм. Мать девочки (возраст 3 года и 9 мес.) была обеспокоена тем, что поведение, рост и развитие ребенка, возможно, нарушены отравлением ртутью. Врачебный осмотр показал некоторую задержку речевого развития при выполнении логопедических упражнений и проблемы с мелкой моторикой; ЭЭГ была в норме. Физически девочка была очень развита для своих лет. Ее рост (108 см) и вес (21 кг) были сопоставимы в среднем с пяти-, шестилетними девочками. Тем не менее, многоэлементный анализ волос показал пониженный уровень многих элементов. Только концентрация фосфора и калия были в норме. Результаты этого случая указывают на то, что развитие организма происходит не равномерным созреванием всех органов одновременно, а в различные для каждого органа и/или системы органов тела периоды. Видимо, в процессе метаболизма поступающая в организм пища, прежде всего, влияет на общий рост и развитие, в связи с чем перераспределение элементов внутри живых организмов происходит таким образом, что элементы расходуются на рост органов, и это проявляется тем, что в волосах их содержание снижается. Действительно, рост организма - сложное многомерное явление, которое все еще не имеет чёткого определения. Наши знания о росте тела, в основном, связаны с ростом в высоту, т.е., ростом костей. Полученные нами сведения продемонстрировали, что рост организма в различных его аспектах (волосы как показатель элементного обмена, линейный рост и вес как антропометрические параметры) имеет различные темпы в соответствующие периоды времени, т.е., внутреннее распределение метаболических ресурсов зависит от стадии роста.

КЛЮЧЕВЫЕ СЛОВА: биологический возраст, волосы, элементный профиль, метаболическое расхождение. 